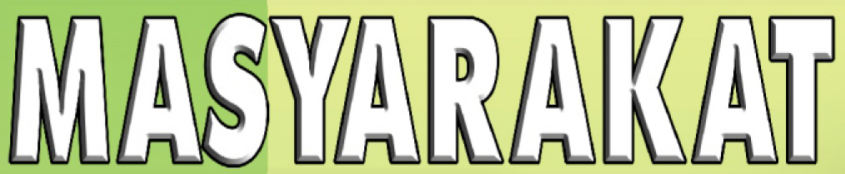

Terakreditasi No. 21/E/KPT/2018
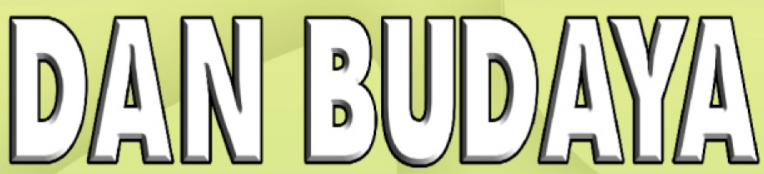

Volume 22 No. 12020

Karakter Keberagamaan di Jawa Pasca Geertz

Gutiono Bayu AJ]

Dayak Kaharingan di Tengah Perubahan Sosial Ekologi dan Praktik Perpindahan Agama dl Perdesaan Kalimantan Tengah

Nindyo Budi Kumoro

MarjinalisasI Hukum Adat pada Masyarakat Adat

The Suartina

Nasionalisme Masyarakat Natuna

Budlana Sotlawan

Frontierisation dan Defrontierisation Sebagal Kerangka untuk Studl Marjinalitas: Kasus Dataran Lindu di Sulawesi Tengah

Greg Acclalo/f dan Muhammad Nasrum

Marjinalisasi Perempuan Kuli Panggul di Pasar Pabean Surabaya

Mitranth Dwi Yuntart

Mencipta Ruang, Menggapal Langit: Pendidikan Publik Kritis dan Ruang Alternatif Minoritas di Yogyakarta dan Bandung Melke Lusye Karrolus dan Firchan Arta Wilaya

Adaptasi Sosial Gay Muslim Indonesia Terhadap Agama dan Keluarga Wisnu Adthariono 


\section{Daftar Isi \\ Jurnal Masyarakat dan Budaya \\ Volume 22 No. 1 Tahun 2020}

Pengantar Redaksi

Halaman

Topik:

iii

Ø5 Karakter Keberagamaan di Jawa Pasca Geertz

Gutomo Bayu Aji

\5 Dayak Kaharingan di Tengah Perubahan Sosial Ekologi dan Praktik Perpindahan Agama di Perdesaan Kalimantan Tengah

Nindyo Budi Kumoro

\5 Marjinalisasi Hukum Adat pada Masyarakat Adat

Tine Suartina

\5 Nasionalisme Masyarakat Natuna

Budiana Setiawan

\5 Frontierisation dan Defrontierisation Sebagai Kerangka untuk Studi Marjinalitas: Kasus Dataran Lindu di Sulawesi Tengah

Greg Acciaioli dan Muhammad Nasrun

§5 Marjinalisasi Perempuan Kuli Panggul di Pasar Pabean Surabaya

Miranti Dwi Yuniarti

\5 Mencipta Ruang, Menggapai Langit: Pendidikan Publik Kritis dan Ruang Alternatif Minoritas di Yogyakarta dan Bandung

Meike Lusye Karolus dan Firdhan Aria Wijaya

\5 Adaptasi Sosial Gay Muslim Indonesia Terhadap Agama dan Keluarga

Wisnu Adihartono

\section{Tinjauan Buku:}

\5 Membicarakan Masyarakat Pinggiran di Indonesia

Riwanto Tirtosudarmo 


\title{
ADAPTASI SOSIAL GAY MUSLIM INDONESIA TERHADAP AGAMA DAN KELUARGA \\ THE SOCIAL ADAPTATION OF GA Y MUSLIM TO RELIGION AND FAMILY
}

\author{
Wisnu Adihartono \\ Sosiolog dan Peneliti Independen \\ Ecole des Hautes Etudes en Sciences Sociales (EHESS), Perancis \\ wisnuadi.reksodirdjo@gmail.com
}

\begin{abstract}
The LGBT groups in Indonesia have little or no power and limited access to fight for their rights. Growing up in a system where one cannot be or say who they truly are, places them in a position where they are in a constant state of having to negotiate life within a hostile environment. This paper will look their (social) adaptation between their religion (Islam) and their family. They have to obey their religion, as well as they also have to obey and respect to their family in order to preserve the family's honor. Those complexities raise a hierarchy, which is side by side with the religious teachings, culture and norms that causes a difficulty for them to come out showing as a gay. For this paper, I took the data from my doctoral research at Ecole des Hautes Etudes en Sciences Sociales (EHESS), France which I completed in 2015. For the purposes of this paper, I only used ten questions that are very closely related to religious and family issues.
\end{abstract}

Keywords: LGBT, social adaptation, gay muslim, religion, family.

\begin{abstract}
Abstrak
Kelompok Lesbian, Gay, Biseksual, dan Transjender (LGBT) di Indonesia memiliki akses yang sangat terbatas untuk memperjuangkan hak-hak mereka. Tumbuh dalam sistem di mana seseorang tidak dapat mengatakan siapa mereka sebenarnya, menempatkan mereka dalam posisi di mana mereka berada dalam keadaan konstan. Mereka harus melakukan adaptasi dalam lingkungan yang bermusuhan. Makalah ini akan melihat adaptasi (sosial) mereka di antara agama (Islam) dan keluarga. Mereka harus mematuhi agama mereka dan juga harus menghormati keluarga mereka untuk menjaga kehormatan keluarga. Kompleksitas itu memunculkan hierarki dalam ajaran agama, budaya, dan norma-norma yang menyebabkan mereka sulit tampil sebagai gay. Untuk makalah ini, saya mengambil data dari penelitian doktoral saya di Ecole des Hautes Etudes en Sciences Sociales (EHESS), Perancis yang saya selesaikan pada tahun 2015. Untuk keperluan makalah ini, saya hanya menggunakan sepuluh pertanyaan yang sangat erat kaitannya dengan agama dan masalah keluarga.
\end{abstract}

Kata kunci: LGBT, adaptasi sosial, gay muslim, agama, keluarga.

\section{Pendahuluan}

Indonesia adalah bangsa yang plural dengan keanekaragaman budayanya menjadi elemen yang tidak terpisahkan dari susunannya. Menurut Badan Pusat Statistik (BPS), Indonesia memiliki setidaknya 1.340 suku atau kelompok etnis yang berbeda. Dengan populasi 260 juta, Indonesia adalah negara terpadat keempat di dunia. Dengan $87,2 \%$ populasi bangsa Indonesia yang sangat identik beragama Islam, Indonesia juga merupakan negara dengan mayoritas penduduk muslim terbesar di dunia. Presiden Soekarnomenyatakan bahwa kaum minoritas agama harus memiliki kepentingan dalam masa depan Indonesia. Dengan demikian, Presiden
Soekarno mengusulkan Pancasila ${ }^{1}$ sebagai filosofi dasar pluralisme negara. Oleh karena itu, Indonesia adalah negara satu untuk semua dan semua untuk satu. Konsep tersebut kemudian diwujudkan dalam semboyan nasional resmi Indonesia, yaitu Bhinneka Tunggal Ika. Semboyan ini memperjelas bahwa para pendiri bangsa Indonesia memiliki kesadaran dan juga menekankan bahwa Indonesia adalah negara

${ }^{1}$ Filosofi dasar Pancasila tersebut berisi: 1 . Ketuhanan Yang Maha Esa, 2. Kemanusiaan yang adil dan beradab, 3. Persatuan Indonesia, 4. Kerakyatan yang dipimpin oleh hikmat kebijaksanaan dalam permusyawaratan/perwakilan, 5. Keadilan sosial bagi seluruh rakyat Indonesia 
yang penuh dengan keanekaragaman budaya dan agama. Namun semboyan itu belum dapat dinikmati oleh individu LGBT (Lesbian, Gay, Biseksual, Transgender). Mengapa?

Alasan pertama adalah bahwa ada banyak orang yang percaya bahwa hubungan sesama jenis dilarang oleh Tuhan dan agama. Akibatnya, LGBT tidak perlu diberi perlindungan atau diberdayakan. Keyakinan ini masih cukup lazim di masyarakat dan masuk dalam kebijakan negara. Akibatnya kekerasan sering dianggap perlu atau diizinkan karena disinyalir mereka berada di jalur yang tidak diampuni oleh Tuhan (Arivia \& Gina, 2016). Alasan kedua adalah bahwa banyak orang percaya LGBT adalah gaya hidup yang dapat dihindari jika seseorang menginginkannya. Gaya hidup ini dipandang sebagai penghancuran dan bertentangan dengan norma yang ada. Hubungan seksual seperti sodomi dipandang sebagai gaya hidup orang asing dan tidak normal.

Karena gaya hidup adalah pilihan, masalah LGBT tidak dilihat sebagai masalah hak asasi manusia tetapi disebabkan oleh kebodohan individu (Arivia \& Gina, 2016). Alasan ketiga adalah bahwa karena komunitas LGBT dipandang memiliki gaya hidup yang terkait dengan kemewahan sehingga diperkirakan tidak ada seorangpun di komunitas LGBT yang hidup di tengah kemiskinan (Arivia \& Gina, 2016). Alasan keempat adalah bahwa orang-orang LGBT sering tidak ingin orientasi seksual mereka diketahui karena malu atau karena alasan keluarga. Mereka menyembunyikan ketertarikan mereka terhadap orang yang mereka cintai. Hal ini sangat berbeda dari pasangan heteroseksual (Arivia \& Gina, 2016). Dengan keempat hal tersebut, kebanyakan dari orang-orang LGBT tidak ingin diketahui apakah mereka gay, lesbian, biseksual atau transgender. Mereka dapat memiliki karakter pria dan wanita biasa pada umumnya tanpa melepaskan orientasi seksual mereka.

Pria gay menjadi minoritas di Indonesia. Mereka sering mendapatkan diskriminasi dan bahkan viktimisasi. Bahkan mereka mendapatkan berbagai macam tindakan seperti kekerasan verbal, penghinaan, ejekan, ancaman (Barrientos et al., 2010), penganiayaan verbal, kekerasan fisik (Biçmen \& Bekiroğullan, 2014) dan bahkan pembunuhan (Gruenewald, 2012). Kekerasan terhadap pria gay juga terjadi di dunia maya. Misalnya, sebuah studi oleh Padva (2008) menunjukkan bahwa kaum gay sering mengalami bullying di berbagai media, seperti di televisi, jurnal, situs web, fiksi, buku cerita anak-anak, komik, musik, iklan, dan pornografi. Kekerasan tidak hanya dilakukan oleh individu atau kelompok lain dalam masyarakat, tetapi juga oleh lembaga negara. Sebuah studi oleh YuRong dan Ping (2010) di Taiwan, misalnya, menunjukkan bahwa kaum gay sering diperlakukan dengan prasangka, permusuhan, dan kekerasan dalam masyarakat di samping perlakuan diskriminatif pemerintah dengan wacana penuh kebencian.

Tulisan ini akan membahas bagaimana para pria gay muslim Indonesia dalam beradaptasi di tengah orientasi seksualnya. Adaptasi yang akan menjadi pokok kajian adalah adaptasi pada agama dan keluarga. Bagaimana mereka mengatasinya adalah hal yang sangat penting di dalam tulisan ini sehingga kita dapat mengetahui apa-apa saja yang mereka adaptasi di dalam kehidupan mereka.

\section{Pilihan Kata Gay dan Metodologi}

Sebelum masuk ke topik utama, saya ingin menjelaskan mengapa saya bersikeras menggunakan kata "gay" daripada "homoseksual. Whitaker (2001) mengatakan bahwa beberapa orang percaya bahwa kata homoseksual" memiliki nada yang cukup negatif. Kebanyakan pria dan wanita homoseksual lebih suka menggunakan kata-kata gay dan lesbian. Menurut Michel Foucault kata homoseksual" selalu dikaitkan dengan istilah patologis. Homoseksual sekarang dianggap menjadi spesies (Foucault, 1980).

Sementara itu, kata gay umumnya digunakan sebagai pernyataan identitas untuk mewakili kedirian, seperti dalam kalimat Saya gay, ini adalah saya, dan ini adalah label yang saya berikan pada diri saya. Dengan demikian, kata ini menjadi semacam kebanggaan yang ada pada diri setiap lelaki gay, baik itu gay maskulin atau gay feminin. Ketika James M. Donovan ${ }^{2}$ dari Tulane University melakukan penelitian tentang homoseksual, gay, dan lesbian, Dia menemukan dari salah satu respondennya titik perbedaan antara kata homoseksual" dan gay. Homoseksual mendefinisikan perilaku sementara

${ }^{2}$ Ketika James M. Donovan melakukan penelitian tersebut, Ia masih berstatus sebagai Kandidat Ph.D 
gay di sisi lain mendefinisikan penerimaan terhadap perilaku dan pola pikir oleh seorang individu sehingga kata"gay menggambarkan cara hidup.

Pengumpulan data dalam tulisan ini hanya dilakukan oleh lima orang gay melalui percakapan informal. Para peserta dipilih berdasarkan karakteristik mereka yang dapat membantu dalam menghasilkan wawasan dan pemahaman tujuan tulisan ini. Para peserta yang diwawancarai untuk makalah ini adalah sukarela. Para responden meminta saya untuk tidak mempublikasikan nama asli mereka sehingga saya hanya menggunakan alfabet $\mathrm{A}, \mathrm{B}, \mathrm{C}, \mathrm{D}$, dan E. Usia responden berkisar antara 25 sampai 35 tahun dan pekerjaan mereka adalah A adalah seorang mahasiswa pascasarjana dan memiliki kekasih seorang Perancis, B adalah seorang mahasiwa pascasarjana dan lajang, $\mathrm{C}$ adalah seorang pekerja di sebuah rumah makan dan memiliki kekasih seorang Perancis, D adalah seorang mahasiswa pascasarjana dan lajang, dan E adalah juga seorang mahasiswa pascasarjana dan memiliki kekasih seorang Belgia. Mereka juga meminta saya untuk hanya menyebutkan usia dan jenis pekerjaan yang mereka sedang kerjakan. Semua interview dilakukan hanya di Paris dan dilakukan di tempat-tempat yang nyaman bagi mereka, seperti di kedai kopi dan rumah makan. Pada dasarnya interview yang saya lakukan adalah interview yang saya kerjakan untuk program doktoral yang telah saya selesaikan pada bulan Oktober 2015 di Ecole des Hautes Etudes en Sciences Sociales (EHESS), Perancis sehingga interview ke lima responden yang saya lakukan telah saya kerjakan pada sekitar bulan Agustus sampai bulan Desember 2011.

\section{Sekilas tentang Kehidupan Komunitas Gay di Jakarta}

Jakarta terletak di barat laut Jawa. Sebagai kota metropolitan, Jakarta mencakup area sekitar $6.175 \mathrm{~km}^{2}$. Jakarta dipimpin oleh seorang gubernur. Pada tahun 2000, Jakarta memiliki total populasi lebih dari 21,6 juta, terdiri dari sekitar $80 \%$ populasi perkotaan dan $20 \%$ populasi pedesaan. Sensus nasional menunjukkan bahwa pada tahun 2010 Jakarta menampung 26,6 juta penduduk. Oleh karena itu, Jakarta adalah kota terpadat di Asia Tenggara.
Di tingkat masyarakat, Anggrahita (2012) mengatakan bahwa masyarakat Jakarta menderita ketimpangan sosial. Ketidaksetaraan ini berakar pada warisan zaman kolonial. Sejauh menyangkut homoseksual, otoritas Hindia Belanda membuat perbedaan (yang sangat tajam) antara laki-laki, perempuan, dan homoseksual. Demikian pula selama rezim otoriter, Presiden Soeharto menerapkan agendanya ke tingkat yang lebih tinggi. Setelah peristiwa politik tahun 1998, ketika rezim otoriter Soeharto ditundukkan oleh kekuatan rakyat dan para mahasiswa, sebaliknya muncul beberapa bar, sauna, klub yang dikhususkan untuk komunitas gay (Forshee, 2006). Munculnya bar dan sauna khusus gay tersebut memberi tanda bahwa Jakarta juga dicap sebagai kota yang ramah dengan gay. Salah satu bar gay yang ramai di Jakarta Selatan adalah Apollo. Bar ini memiliki stadion"atau lantai dansa dengan sistem suara dan pencahayaan penuh. Beberapa Disc Jockey (DJ) paling berbakat menghidupkan bar ini dengan musik top 40, progresif, dan house music.

Selain itu kita juga bisa melihat beberapa go-go dancers atau penari go-go yang seksi, jantan, dan berotot. Sebagian besar gay yang datang ke bar ini berasal dari kelas menengah atas. Selain itu, ada pula Atlantis yaitu sauna yang dikhususkan bagi komunitas gay. Sauna ini memiliki slogan Do come in and have a good fuck. Atlantis menawarkan interior modern dengan peralatan lengkapnya, ruangan gym sebesar $60 \mathrm{~m}^{2}$, sauna sebesar $150 \mathrm{~m}^{2}$, ruang uap, kamar gelap dan 16 kabin pribadi. Mirip dengan Atlantis, 9M dapat ditemukan di sekitar jalan Sudirman di jantung kota Jakarta. 9M juga merupakan sauna khusus untuk komunitas gay yang cukup menarik banyak komunitas gay di Jakarta. Selain itu, Nirvana juga merupakan bar gay alternatif di Jakarta. Buka dari Rabu hingga Senin pagi dan menyelenggarakan malam dengan berbagai macam tema. Nirvana menawarkan pertunjukan penari go-go, drag queen, serta topless nights.

Melihat kemunculan tempat-tempat khusus gay di Jakarta, maka dapat dikatakan bahwa Jakarta saat ini'"adalah kota yang cukup ramah dengan gay. Jika kita melihat perkembangan bar dan sauna gay di Jakarta, tentu ini sangat bertentangan dengan Islam yang masuk ke Indonesia dan ini telah menjadi benturan budaya yang cukup keras. 


\section{Dogma Islam di Indonesia}

Secara luas diyakini bahwa homoseksualitas dilarang dalam Islam. Di bawah hukum beberapa negara Islam, tindakan homoseksual dianggap sebagai kejahatan dan dihukum mati (Ahmadi, 2012). Komunitas gay tidak dilindungi secara hukum. Islam sangat mempertahankan heteronormativitas dengan argumen moral. Beberapa cendekiawan berpendapat bahwa ini karena AlQur'an mengutuk homoseksualitas bahkan lebih tegas daripada yang dilakukan oleh tulisan suci Ibrani dan Kristen (Ahmadi, 2012).

Apabila masalah homoseksualitas dikaji secara lebih luas tentu saja kita dapat melihat interpretasinya dalam syariah. Dalam bahasa Arab, syariah didefinisikan sebagai jalan. Muslim umumnya memahami Syariah sebagai prinsip panduan tentang bagaimana seseorang harus hidup sehari-hari, memperhatikan kewajiban keluarga dan agama, dan menyusun keuangan dan bisnis.

Sementara itu, syariah sering digunakan sebagai dasar hukum Islam. Syariah dalam hal ini adalah perkataan, praktik, dan ajaran Nabi Muhammad. Para sarjana muslim menggunakan Syariah untuk mengidentifikasi preseden dan membangun analogi yang mempengaruhi kode di beberapa negara Muslim (Johnson \& Vriens, 2011). Cendekiawan syariah umumnya menganggap homoseksualitas sebagai kejahatan, bukan hanya dosa (Duran, 1993). Syariah jelas menggambarkan bahwa hukuman untuk homoseksualitas diserahkan pada kebijaksanaan otoritas (Duran, 1993). Duran (1993) juga mengatakan bahwa masalah itu diserahkan pada kebijaksanaan Nabi Muhammad dan kemudian pada kebijaksanaan para ahli hukum untuk memutuskannya. Syariah dapat dianggap sebagai ekspresi kehendak Tuhan melalui wahyu (Ahmadi, 2012).

Di Indonesia, umat Islam dihubungkan dengan keyakinan, warisan, dan kepercayaan Islam melalui satu Tuhan, malaikat, buku-buku Tuhan yang diwahyukan, para nabi, hari penghakiman, pertanggungjawaban individu atas tindakan, dan kehidupan setelah kematian (Rassool GH., 2003). Orang-orang muslim memandang Al-Qur'an ungkapan kata-kata yang tepat yang diungkapkan oleh Allah melalui malaikat Jibril kepada Nabi Muhammad dan seterusnya kepada orang-orang (Ibrahim K \& Songwathana P., 2009). Dengan demikian, AlQur'an berfungsi sebagai sumber utama dari keyakinan dan praktik kehidupan setiap muslim.
Islam adalah agama yang memasukkan praktik ritual. Lima rukun Islam meliputi: keimanan shalat, zakat, puasa), dan naik haji (bagi mereka yang mampu) ke Mekah (Ibrahim K \& Songwathana P., 2009). Islam juga mendefinisikan budaya dan budaya memberi makna pada setiap aspek kehidupan individu, termasuk perilaku, persepsi, emosi, bahasa, struktur keluarga, diet, pakaian, tubuh, konsep ruang dan waktu, dan sikap terhadap kesehatan dan penyakit (Ibrahim K \& Songwathana P., 2009). Islam memandang pernikahan sebagai hal yang sakral dan keluarga sebagai fondasi masyarakat. Pria dipandang sebagai pelindung wanita dan memainkan peran penting dalam pengambilan keputusan (Ibrahim K \& Songwathana P., 2009).

Homoseksualitas dikutuk, dianggap berdosa, dan dihukum oleh Allah. Pasangan muslim didorong untuk memiliki anak, seks di luar nikah tidak dianjurkan dan kontrasepsi dan keluarga berencana diperbolehkan (Ibrahim K \& Songwathana P., 2009). Aborsi tidak diizinkan, kecuali jika kehamilan mengancam kehidupan ibu karena anak-anak dianggap sebagai hadiah dari Allah. Anak laki-laki disunat antara usia tujuh dan dua belas tahun untuk menjaga kebersihan dan untuk mencegah air seni mengumpul di kulit khatan (Ibrahim K \& Songwathana P., 2009). Umat muslim lebih suka dirawat oleh anggota dengan jenis kelamin yang sama.

Selain itu, kepercayaan Islam menekankan kebersihan yang meliputi mencuci area genital dengan air mengalir sebelum semua jenis ibadah, makan dengan tangan kanan, dan hanya mengkonsumsi makanan yang diizinkan (halal). Makanan dan barang terlarang atau tidak diizinkan (haram) yaitu daging babi, minuman beralkohol, produk gelatin, dan obat-obatan terlarang (Ibrahim K \& Songwathana P., 2009). Berbicara tentang kematian, setelah kematian mata dan mulut orang tersebut harus ditutup dan anggota tubuh harus diluruskan. Ritual mencuci tubuh lengkap harus dilakukan oleh anggota keluarga atau orang dengan jenis kelamin yang sama. Tubuh harus ditutup dengan selembar kain kafan dan doa harus diucapkan. Beberapa Muslim mungkin meminta non-muslim untuk tidak menyentuh tubuh mayat tersebut dan mayat dikuburkan sesegera mungkin setelah kematian (Ibrahim K \& Songwathana P., 2009).

"Model bisnis"Islam identik dengan kepercayaan monoteistik yaitu adanya satu 
Tuhan Sang Pencipta. Manusia akan dihukum sesuai dengan perbuatannya di akhirat. Setiap individu diyakini memiliki hubungan langsung dengan Tuhan (Khan, 2010). Karena Islam memiliki "model bisnis" yang begitu ketat, Islam sangat melarang hubungan seksual yang mencakup hubungan sesama jenis. Pembenaran untuk larangan ini didasarkan pada kenyataan bahwa hubungan ini berjalan di luar kontrak pernikahan (Siker, 2007).

Terkait dengan LGBT yang menjadi polemik di masyarakat Indonesia, Majelis Ulama Indonesia (MUI) telah menetapkan hukum untuk masalah ini melalui Fatwa Nomor 57 tahun 2014 tentang Lesbian, Gay, Sodomi, dan Kecabulan. Fatwa ini didasarkan pada keinginan masyarakat untuk memiliki ketentuan hukum yang jelas tentang LGBT. Sebagai lembaga yang berwenang untuk menetapkan hukum Islam, MUI telah mengkaji dan merumuskan fatwa tentang hukum LGBT menurut Islam (Usman, 2018). Dalam fatwa tersebut, MUI menetapkan sebelas poin hukum yang terkait dengan LGBT yaitu (MUI, 2014) sebagai berikut.

(1) Hubungan seksual hanya diperbolehkan untuk pasangan yang memiliki hubungan suami-istri.

(2) Orientasi seksual ke sesama jenis adalah kelainan yang harus disembuhkan dan penyimpangan itu harus diluruskan.

(3) Homoseksual, baik lesbian maupun gay dilarang (haram) dan merupakan bentuk kejahatan (jarimah).

(4) Pelaku homoseksual, baik lesbian maupun gay, termasuk biseksual harus tunduk kepada pihak berwenang.

(5) Sodomi dilarang dan merupakan tindakan keji yang membawa dosa besar (fahishah).

(6) Pelaku Sodomi harus dihukum mati.

(7) Kegiatan homoseksual dilarang dan pelakunya dikenakan hukuman.

(8) Aktivitas seksual seperti meraba dan meremas dan aktivitas lain tanpa adanya ikatan sah dari suatu pernikahan dilarang.

(9) Orang yang tidak senonoh sebagaimana dimaksud dalam angka 8 dikenakan hukuman.

(10) Dalam kasus korban kejahatan homoseksual, pelaku akan dikenakan hukuman mati.

(11) Aktivitas seksual sesama jenis dan orientasi seksual menyimpang lainnya dilarang.

Berdasarkan fatwa, dapat dipahami bahwa MUI memandang perilaku LGBT sebagai bentuk penyimpangan seksual yang melanggar hukum dan harus dijauhi oleh umat Islam (Usman, 2018). Mengacu pada Al-Quran, MUI memberlakukan hukuman pada perilaku LGBT. Lembaga pertimbangan hukum menganggap perilaku LGBT telah menyimpang dari kodrat manusia yang Tuhan tentukan. Melalui hubungan dengan lawan jenis, manusia dapat berkembang biak dan membawa keturunan. Oleh karena itu, MUI melarang LGBT meluas dalam masyarakat (Usman, 2018).

\section{Adaptasi Sosial Gay Muslim Indonesia terhadap Agama}

Hal yang juga sangat penting dijelaskan di dalam tulisan ini adalah tentang adaptasi (sosial). Manusia dapat bertahan hidup dari hasil memanfaatkan potensi alam yang ada di sekelilingnya. Hewan, tumbuhan, udara, air, mineral, dan semua yang ada di di alam semesta ini diambil manfaatnya untuk memenuhi kebutuhan hidup manusia. Manusia adalah makhluk yang paling sempurna dibandingkan dengan makhluk-makhluk lain karena manusia dibekali dengan akal. Dengan akal ini manusia tumbuh menjadi makhluk yang cerdas. Seiring berjalannya waktu dan dengan bertambahnya kecerdasan otak manusia, manusia yang awalnya hanya mampu mengandalkan makanan dari lingkugan (food gathering) menjadi mampu membuat alat yang dapat digunakan untuk mengolah makanan dan bercocok tanam sehingga hidup manusia tidak lagi menetap (Mahmud, 2016).

Konsep adaptasi datang dari dunia biologi di atas memaparkan dua poin penting, yaitu evolusi genetik yang berfokus pada umpan balik dari interaksi lingkungan, dan adaptasi biologi yang berfokus pada perilaku dari organisme selama masa hidupnya. Organisme tersebut berusaha menguai faktor lingkungan yang tidak hanya faktor umpan balik lingkungan tetapi juga proses kognitif. Asumsi dasar adaptasi berkembang dari pemahaman evolusioner yang melihat manusia selalu berupaya untuk menyesuaikan diri dengan lingkungan alam sekitarnya. Adaptasi juga merupakan suatu proses yang dinamis karena baik organisme ataupun lingkungan tidak ada yang bersifat tetap.

Jadi, menurut Gerungan (1991), adaptasi adalah suatu penyesuaian pribadi terhadap lingkungan. Penyesuaian ini dapat berarti mengubah diri pribadi sesuai dengan keadaan lingkungan atau dapat berarti mengubah 
lingkungan sesuai dengan keadaan pribadi. Interaksi sosial yang merupakan dasar dari semua proses sosial pun menjadi dasar dari terbentuknya proses adaptasi (sosial). Syaratsyarat interaksi sosial seperti tindakan sosial, kontak sosial, dan komunikasi sosial termasuk ke dalam indikator adaptasi (sosial) seseorang. Selain itu bentuk-bentuk interaksi sosial seperti kerja sama, persaingan, konflik, serta asimilasi pun masuk ke dalam indikator adaptasi (sosial) seseorang.

Ketika berbicara tentang adaptasi (sosial), kita memfokuskan diri kepada kelompok sosial. Kelompok ini tidak secara langsung teramati tetapi mereka merupakan abstraksi dari perilaku individu. Perilaku adalah respon yang dianggap paling cepat dan fleksibel. Dinamika adaptasi (sosial) mengacu pada perilaku yang didesain (khusus) pada pencapaian tujuan dan kepuasan kebutuhan dan keinginan individu.

Pada titik ini, saya bertemu dengan responden A. Dia adalah seorang mahasiswa pascasarjana dan memiliki seorang kekasih berkewarganegaraan Perancis. Kami bertemu di salah satu kedai kopi tidak jauh dari tempat dia menuntut ilmu. Dia mengenakan kemeja berwarna abu-abu, celana panjang jeans, dan sepatu kets. Sebelum saya mewawancarainya, dia mulai menyalakan rokok. Setelah kami berbicara tentang kehidupannya di Paris, saya langsung bertanya kepadanya. Berikut ini adalah petikan wawancaranya.

Saya (S):

Senang gak tinggal di Paris?

Responden $A(A)$ :

Senang banget mas, wah di sini semuanya bebas banget, gak kayak di Jakarta yang semuanya serba dilarang

$S:$

Maksudnya gimana nih?

A:

Yah mas ngerti sendirilah, orang-orang kayak gimana yang dilarang, $y a$ seperti aku gini lah mas

$S:$

Terus gimana kamu beradaptasi dengan agamamu? Bukannya agamamu sangat kontra dengan homoseksualitas?

A:

Aku tahu mas (Ia menyalakan rokok kembali). Kalau di Jakarta aku sih berperan sebagai laki-laki mas, tapi kalau di sini, kalau saya sedang kumpul dengan orang- orang Perancis, aku bisa ngondek $^{3}$. Tapi kalau aku lagi kumpul dengan orang-orang Indonesia, aku sih jadi laki mas. Maksudnya aku berperilaku kayak laki mas.

$S:$

Kenapa begitu?

$A$ :

Aku males dengan orang Indonesia mas, mereka suka sekali ngomongin orang, gak di belakang, gak di depan, itu yang buat aku harus berperilaku sebagai laki-laki di depan mereka. Aku tetap shalat, puasa, dan bayar zakat mas. Aku tahu Islam tidak memperbolehkan homoseksualitas mas tapi mau gimana lagi mas. Aku gak bisa dengan perempuan. Aku suka dengan laki-laki. Pokoknya aku tetap shalat dan menjalankan kewajiban-kewajiban Islam aku mas. Gak tau deh apakah Allah masih mau menerimaku tapi aku tetap melakukannya. Hanya Allah yang tahu apa yang aku lakukan. Biarin aja mas. Orang lain gak perlu tahu. Aku suka sebel kalau aku lagi pulang ke Jakarta, mau ngondek aja harus cari tempat dulu, capek mas

$S:$

Terus kamu mau balik ke Indonesia atau menetap di Paris?

A:

Sekarang aku sudah punya pacar orang Perancis, dia sangat baik mas. Nanti kalau sekolahku sudah selesai kayaknya aku gak akan balik ke Indonesia. Ya balik paling cuma sebentar mas. Tapi aku sudah bilang ke pacarku kalau aku pengen tinggal di Paris

Dari percakapan tersebut, saya mengambil kesimpulan bahwa A sangat tidak nyaman tinggal di Indonesia karena masyarakat, agama, dan pemerintah yang selalu melihat homoseksualitas sebagai korban. Hal ini ditanggapi lain oleh B. B adalah seorang mahasiswa pascasarjana dan masih lajang. Dia datang ke sebuah kedai kopi yang tidak jauh dari apartemennya. Dia berpakaian sangat santai. Dia hanya mengenakan kaus putih, bercelana jeans, dan bersepatu kets. Dia berperilaku seperti perempuan di depan saya dengan sesekali menyalakan rokoknya. Oleh karena B memiliki sifat yang sangat riang gembirang maka saya menggunakan kata ganti $l u$ dan gue dalam percakapan kami.

\section{Responden B (B):}

Hai mas, apa kabarnya sih nek?

\section{Saya (S):}

$\mathrm{Gue}^{4}$ baik

${ }^{3}$ Ngondek adalah berperilaku seperti
${ }^{4}$ Gereme berarti Saya dalam bahasa Betawi


Setelah kami berbincang-bincang seadanya, percakapan saya arahkan kepada masalah adaptasi dalam agama.

$S:$

Gimana nih $l u^{5}$ beradaptasi dengan agama $l u$ ?

B:

Karena gue beragama Islam, gue sih ya tetep shalat walaupun banyak bolongnya mas. Seperti biasa aja lah mas. Gue sih tetep inget kalau gue masih punya Allah. Gitu aja mas, simple kan?

S:

Terus apa $l u$ juga puasa dan bayar zakat?

B:

(Sambil tertawa agak lebar) Gue puasa juga bolongbolong mas, kalau bayar zakat sih gue gak mas. Gue kan dapet beasiswa untuk sekolah di Perancis, wah kalau uang gue untuk bayar zakat gue takut kalau uang gue gak cukup. Yang penting gue shalat dan puasa aja lah mas. Yah siapa tahu aja nanti kalau gue pulang ke Jakarta, gue bisa bayar zakat

$S:$

Lu mau pulang ke Jakarta?

B:

Belum tahu mas, ini kalau S2 gue udah selesai sih pengennya cari S3 di Perancis tapi harus pakai beasiswa. Kalaupun gue balik ke Indonesia, paling cuma sebentar aja untuk cari beasiswa.

Karena B masih lajang, B merasa bahwa dia tidak perlu melakukan aktivitas keagaamaan. B merasa dengan kelajanganannya dia masih dapat mencari kesenangan dengan pria-pria Perancis.

Berbeda dengan responden A dan B, responden $\mathrm{C}$ memiliki pandangan agama yang sangat religius. Kami bertemu di sebuah kedai kopi Perancis yang menjual croissant, roti khas Perancis, dan kopi. Kami memesan croissant dan dua kopi. Mukanya agak sedikit lelah karena kami bertemu setelah dia pulang bekerja. Tampak dari raut mukanya yang sedikit tegang ketika percakapan akan dimulai. Saya sebagai peneliti dapat merasakan"aura ketegangan tersebut. Tanpa merusak suasana, saya membahas kehidupannya terlebih dahulu di Perancis dan setelah dia tersenyum lalu saya mulai bertanya tentang adaptasi yang dilaluinya.

Saya (S):

Bagaimana kamu beradaptasi dengan agamamu sementara kamu adalah seorang gay?

Responden C (C):

Aku melakukan adaptasi dengan cara biasa saja. Aku shalat lima waktu dan berpuasa. Aku juga bayar zakat

${ }^{5} \mathrm{Lu}$ berarti Kamu dalam bahasa Betawi dengan teratur. Kalau sedang berkumpul dengan orang-orang Indonesia, aku akan menjadi seorang laki-laki tulen. Begitupun kalau aku sedang bersama orang Perancis yang homofobi. Jangan salah ya mas, di negara yang maju seperti Perancis, homofobi masih terus ada jadi aku akan bersikap seperti laki-laki. Tetapi ketika aku sedang di kawasan Le Marais ${ }^{6}$, aku bisa menjadi aku yang sebenarnya. Aku bisa berperilaku seperti perempuan. Aku tahu bahwa menjadi gay itu salah tapi aku gak bisa munafik mas. Aku suka laki-laki mas.

$S:$

Tapi kamu kan punya pacar?

C:

Saya ke Le Marais dengan pacar saya mas. Kebetulan pacar saya orangnya sangat over-protective. Saya suka. Jadi saya menikmati saja ke-over-protectiveannya (sambil tertawa kecil).

Dalam hal ini responden $\mathrm{C}$ sangat santun. Dia menaati hampir semua peraturan yang Islam miliki. Dia melakukan shalat lima waktu, berpuasa, dan melakukan zakat. Dia sangat sadar bahwa menjadi gay itu salah dan sebagai alat untuk menutupi kesalahannya, dia melakukan semua peraturan-peraturan yang Islam miliki.

\section{Adaptasi Sosial Gay Muslim Indonesia terhadap Keluarga}

Pada bagian ini hal yang harus diketahui terlebih dahulu adalah definisi keluarga. Keluarga memiliki definisi yang sangat luas. Salah satu definisi keluarga yang dapat diberikan adalah dari Hareven (1988) yang menjelaskan bahwa keluarga adalah salah satu lembaga sosial paling kompleks. Hal ini dipengaruhi oleh proses biologis, dinamika psikologis, nilai-nilai budaya, kondisi pasar, perubahan demografis, lembaga kapitalisme industri, gereja, lembaga perencanaan kesejahteraan, dan perubahan historis jangka panjang.

Keluarga itu sendiri bukanlah unit yang statis dan homogen melainkan organisasi yang kompleks dengan konfigurasi usia dan jenis kelamin yang berbeda. Keluarga terdiri dari suami dan istri, orang tua dan anak-anak, saudara lelaki dan perempuan, kakek, nenek dan cucu,

${ }^{6}$ Le Marais adalah kawasan yang dikhususkan untuk kelompok homoseksual di Paris. Akan tetapi saat ini kawasan Le Marais banyak dikunjungi heteroseksual yang ingin melihat kawasan ini. Di kawasan Le Marais banyak ditemukan toko-toko, hotel-hotel, dan bar-bar yang mengibarkan bendera pelangi 
dan berbagai kerabat lainnya yang terikat satu sama lain oleh ikatan darah serta oleh berbagai ikatan sosial, emosional, dan moral. Seiring munculnya wacana homoseksualitas di dunia Barat, konsep dan definisi keluarga juga telah berubah. Menurut Segalen (2006), institusi keluarga terutama berubah sejak 1960-an. Dia mengatakan bahwa secara teratur media mengingatkan kerentanan pernikahan, peningkatan perceraian, timbulnya keluarga tiri, dan sebagainya.

Di kawasan Asia, keluarga pada umumnya didominasi oleh hubungan yang monogami dan patrilineal. UNESCO yang dikutip oleh Elliot dan Gray (2000) mengatakan bahwa di Asia suami hanya memiliki satu istri. Keturunan diperhitungkan hanya melalui garis laki-laki dan otoritas berada hanya pada laki-laki. Permasalahan tempat tinggal juga bersifat patrilokal. Para istri (harus) pindah ke rumah orang tua suami setelah menikah. Sistem keluarga di Indonesia didasari pada keluarga nuklir atau keluarga inti, yaitu sistem keluarga yang hanya terdiri dari suami, istri, dan anak. Model keluarga ini banyak digunakan di Indonesia karena model ini berfokus pada hubungan antar anggota keluarga (Elliot\&Gray, 2000).

Karena banyaknya penggunaan model ini di Indonesia, Badan Kependudukan dan Keluarga Berencana Nasional (BKKBN) telah mendefinisikan keluarga di Indonesia sebagai unit terkecil dalam masyarakat yang terdiri dari suami, istri, dan anak atau ayah dan anaknya atau ibu dan anaknya. Secara implisit dalam batasan ini yang dimaksud dengan anak adalah anak yang belum menikah. Model keluarga inti, secara historis dan sosiologis, dipengaruhi oleh ideologi negara Indonesia, yaitu Prinsip keluarga atau azas kekeluargaan (Boellstorff, 2005: 117).

Dalam perkembangannya, model keluarga inti dikaitkan dengan model masyarakat tradisional Jawa yang menekankan kerjasama, kesesuaian, otoritas, dan hubungan yang harmonis (Koentjaraningrat, 1985). Dengan keunggulan budaya Jawa, Presiden Soeharto telah mencoba untuk mengembalikan budaya Jawa sebagai poros dunia (Anderson, 1990). Dengan cara ini, hampir semua model keluarga di Indonesia menggunakan model keluarga Jawa. Dalam model ini, orang tua mengajar anak mereka untuk membantu, berbagi, dan berempati dengan orang lain (Williams, 1991), sementara orang tua berharap anak-anak tetap tenang, patuh, dan menghormati orang tua mereka (Koentjaraningrat, 1985). Dengan kata lain, hubungan antara orang tua dan anak-anak dalam keluarga Indonesia mencerminkan representasi keluarga. Dalam hal ini, Aoki, Ngin, Mo, dan Ja (1989) menjelaskan bahwa seseorang tidak dipandang sebagai individu, tetapi sebagai wakil dari keluarganya. Kehilangan muka memiliki akibat yang (cukup) serius karena hal itu mencerminkan secara negatif pada seluruh keluarga dan bukan hanya pada individu tersebut.

Posisi anak laki-laki juga sangat sulit di Indonesia. Wirakartakusuma (1997) menunjukkan bahwa terdapat norma sosial yang menempatkan seorang anak harus mematuhi orang tuanya. Dia menjelaskan bahwa norma sosial di Indonesia menetapkan bahwa seorang anak harus menghormati orang tuanya. Anak yang mengabaikan dan yang tidak peduli dengan orang tua mereka akan dikenakan sanksi sosial. Norma yang menuntut anak-anak untuk menghormati orang tua mereka tetap berlaku dan dipatuhi oleh orang Indonesia. Seorang anak laki-laki di Indonesia (biasanya) takut terhadap figur ayah. Tidak seperti figur seorang ibu yang secara psikologis memiliki perasaan yang lebih positif daripada seorang ayah (Savin-Williams, 1990). Di Indonesia hal ini disebarluaskan sebagai figur bapak atau kebapakan. Mengenai hal ini Boellstorff (2015) menjelaskan bahwa gagasan tentang laki-laki modern yang "kebapakan" ini terbentuk pada masa Orde Baru dan disosialisasikan oleh negara. Presiden Soeharto menyebut dirinya bapak sebagai lawan dari saudara yang seringkali digunakan pada masa Presiden Soekarno.

Kondisi ini membuat citra ayah menjadi sosok yang (sangat) ditakuti terutama oleh anak laki-laki yang gay. Dalam kasus seperti ini, orang tua mengadopsi gaya pengasuhan yang otoritatif daripada gaya pengasuhan yang permisif. Ciri khas gaya pengasuhan otoritatif biasanya adalah orang tua meminta banyak hal tanpa alasan khusus. Akibatnya, permintaan dari orang tua ini umumnya tidak sesuai untuk kebutuhan anak dan anak tersebut tidak mempunyai pilihan selain menghormati orang tuanya. Kalimat-kalimat seperti Ayo dong tunjukkan kalau kamu laki-laki!, Jangan nangis dong, jangan takut, kuat, kamu kan laki-laki", (Deloison, 2014), dan buktikan jika kamu lakilaki'(Badinter, 1992) adalah kalimat yang selalu diucapkan oleh orang tua terutama oleh ayah 
kepada anak laki-lakinya. Maksud dari kalimatkalimat tersebut adalah mengajak anak laki-laki untuk berkompetisi dan membuktikan keagresifitasannya (Deloison, 2014). Seorang laki-laki diprogram sedemikian rupa untuk berkompetisi. Adrenalin mereka dipicu untuk menghadapi tantangan dan mereka juga harus selalu menang (Deloison, 2014). Oleh karena itu, seringkali kita mendengar kata "gentlemen". Yang juga menarik dari seorang laki-laki di Indonesia adalah mereka sering diidentikkan dengan olahraga sepakbola yang diidentikkan dengan "kekuatan maskulin" (Deloison, 2014).

Di Indonesia, seorang laki-laki yang memiliki orientasi seksual yang gay kebanyakan menutup diri mereka. Ditambah lagi orang tua yang memiliki seorang anak laki-laki yang gay merasa malu karena mereka merasa tidak dapat mendidik anak laki-laki mereka dengan baik dan benar. Sebagai konsekuensinya, ketika para orang tua ditanya apa orientasi seksual anak mereka, para orang tua menjawab bahwa anak mereka adalah anak-anak yang normal.

Pada bagian ini, saya menemui dua responden tersisa. Responden D adalah mahasiswa pascasarjana dan masih berstatus lajang. Kami bertemu di salah satu kedai kopi tidak begitu jauh dari kampusnya. Ketika saya menemuinya, responden $\mathrm{D}$ terlihat sangat periang dan sangat membantu penelitian saya. Oleh karena itu, saya langsung memilih menggunakan kosa kata $l u$ gue. Setelah kami berbincang-bincang secara santai mengenai kota Paris, kemacetan kota Paris, dan suhu udara di kota Paris, saya langsung bertanya mengenai adaptasi yang dia lakukan terhadap keluarga inti di Indonesia dan keluarga kecilnya di Paris.

\section{Saya (S):}

Gimana sih caranya lu bisa beradaptasi dengan keluarga inti $l u$ di Indonesia?

\section{Responden D (D):}

Gampang aja mas (sambil menyalakan rokok dan meminum sedikit kopi). Gue sih wajar-wajar aja. Kalau di Indonesia dan lagi kumpul dengan keluarga, gue berkelakuan kayak laki. Tapi kalau di sini karena masyarakatnya kebanyakan juga masa bodoh ya gue bisa berkelakuan kayak perempuan.

$S:$

Orang tua lu gak paham kalau lu memiliki dua perilaku?

D:

(sambil tertawa sangat lebar) Gak mas, sama sekali gak tahu. Kalau tahu gue bisa dipancung mas.
Keluarga gue adalah keluarga yang sangat Islam. Satu adik perempuan gue masuk pesantren. Bokap gue kyai, nyokap ${ }^{8}$ gue guru ngaji. Wah kalau ketahuan kan berabe mas.

\section{$S:$}

$O k$, terus hanya dengan bersikap begitu saja $l u$ beradaptasi dengan keluarga inti?

D:

Iya mas. Abis mau dengan cara apa lagi. Bagi masyarakat Indonesia kebanyakan gak mungkin kita berbicara jujur di depan orang tua. Jangankan di depan orang tua, di depan teman yang baik pun kita pasti akan berpikir ribuan kali. Orang Indonesia sukanya ngomongin orang mas, gak suka gue. Makanya gue ikut beasiswa dan keterima di Paris.

$S:$

Kalau dengan keluarga kecil lu gimana?

D:

Nah ini berbeda mas. Dengan keluarga kecil gue, gue bebas mau berlaku apa aja tapi gue tetap hormat dengan mereka. Kebetulan orang tua angkat gue adalah orang Perancis keturunan Spanyol dan Itali. Mereka sangat permisif dengan lesbian dan gay bahkan dengan transeksual. Mereka pernah bilang ke gue kalau mereka tidak apa-apa punya anak yang gay, lesbian, biseksual, atau transeksual. Yang penting mereka bisa membuat bangga kedua orang tuanya. Itu aja mas permintaan mereka. Mereka juga bilang kalau gue sebagai anak angkat mereka di Paris juga boleh menjadi gay, lesbian, biseksual bahkan transeksual asalkan itu tadi gue harus bisa membanggakan mereka. Gue tetap sholat di Paris walaupun suka bolong-bolong, gue tetap puasa kalau pas Ramadhan, dan waktu sholat gue juga meminta kebaikan untuk keluarga gue di Paris dan Jakarta. Hidup dan mati hanya Allah yang tahu mas. $Y a$ kita terima saja. Kalau gue harus suka dengan laki-laki kenapa harus dilarang?

$S:$

Ingin kembali ke Jakarta?

D:

Pertanyaan yang sulit dijawab. Yah lihat saja nanti mas. Setelah gelar master gue raih rasanya gue pengen kuliah doktoral lagi tapi bukan di Perancis. Gue pengen menikmati Eropa mas. Yah mungkin gue akan pulang sebentar, yang pasti untuk bertemu keluarga gue dan teman-teman baik gue. Gue masih lajang mas, jadi gue masih bebas untuk cari pacar laki-laki.

Cerita yang cukup tragis dialami oleh responden terakhir, responden E. Kami bertemu di sebuah taman yang bersebelahan dengan apartemennya. Responden E adalah seorang

\footnotetext{
${ }^{7}$ Bokap adalah Bapak/Ayah/Papa

${ }^{8}$ Nyokap adalah Ibu/Mama
} 
mahasiswa pasca sarjana dan memiliki seorang kekasih laki-laki dari Belgia. Dia cukup merasa takut untuk menemui saya karena perjanjian kami sempat terundur waktunya dari hari yang ditentukan. Dia mengatakan kepada saya bahwa apabila ceritanya akan dipublikasikan, saya hanya diperbolehkan mencantumkan alfabet, usia, dan pekerjaannya. Setelah saya menjelaskan maksud kedatangan dan pertemuan saya dengan dirinya, Dia merasa sedikit tenang. Dia mencoba untuk menghembuskan nafas beberapa kali dan menyalakan rokok. Dari informasi yang saya dapatkan, ternyata responden $\mathrm{E}$ mendapatkan kekerasan fisik dan kekerasan seksual dari pasangannya ketika mereka berada di Jakarta. Ketika itu dia melakukan hubungan intim dengan kekasihnya seorang Indonesia. Mereka sudah hidup bersama di Jakarta tanpa sepengetahuan orang tuanya. Pada saat mereka berhubungan seksual, kekasihnya selalu melakukan kekerasan seksual begitu pula pada saat mereka tidak melakukan hubungan seksual. Orang tua responden E juga melakukan kekerasan. Orang tua responden $\mathrm{E}$ tidak suka melihat apabila anaknya menjadi seorang gay.

Saya (S):

Boleh cerita sedikit siapa kamu secara singkat saja $y a$ ?

Responden $E(E)$ :

Nama saya E, umur 35 tahun. Saat ini saya sedang kuliah master di salah satu kampus terbaik di Perancis. Terima kasih ya Allah (sambil menghisap rokok) saya telah pindah ke Paris

$S:$

Ada pengalaman apa di diri kamu sehingga kamu mengucap terima kasih kepada Allah?

E:

Panjang ceritanya mas. Tapi saya coba cerita sedikit $y a$. Orang tua saya tidak suka punya anak gay. Kakak saya adalah seorang polisi dan kedua adik saya sekolah di sekolah Islam. Saya juga dulu sekolah di sekolah Islam. Orang tua tahu kalau saya gay ketika saya ketahuan sedang berpelukan dengan teman saya yang saya temui dari aplikasi gay. Saya lupa kunci pintu mas. Ketika itu ayah saya masuk begitu aja ke dalam kamar saya yang tidak terkunci dan saya sedang berpelukan. Saya tidak diusir dari rumah. Saya tetap diijinkan tinggal di rumah tetapi sejak itu sikap keluarga saya semua berubah drastis. Ayah dan ibu saya selalu kasar terhadap saya. Kakak saya juga kasar terhadap saya, bahkan adik saya yang seharusnya hormat pada saya sebagai kakaknya juga berlaku kasar.

$S$ :

Kamu punya pacar pada waktu itu?
E:

$Y a$ saya punya pacar mas tapi $y a$ namanya juga manusia mas. Pacar saya juga sangat keras terhadap saya. Saya selalu mendapatkan kekerasan seksual. Pacar saya itu orangnya suka sekali dengan sado ${ }^{9}$ mas. Pernah saya dicambuk dulu sebelum main, dan lain-lain. Kalau kami tidak main"pun, pacar saya selalu kasar. Saya pernah ditampar karena suatu kesalahan yang sangat kecil. Mas, boleh tidak kalau saya tidak membicarakan dia lagi, sakit sekali mas.

$S:$

Baik, terus bagaimana kamu bisa ke Paris?

E:

Setelah putus dari pacar saya, kebetulan pada waktu itu saya melihat sebuah iklan. $Y a$ saya coba-coba saja mas. Kebetulan saya paling tidak bisa berbahasa Perancis, $y a$ sudah saya coba dan Alhamdulillah saya lolos

$S:$

Ketemu dengan pacar kamu yang orang Belgia di mana?

E:

Oh itu juga kebetulan mas. Singkat cerita ketika saya lagi ngopi di salah satu kedai kopi, semua tempat penuh, cuma ada satu tempat di depan saya. Pada saat itu, Dia datang ke depan saya dan minta izin untuk duduk. $Y a$ sudah saya bolehkan. Setelah beberapa jam kami ngobrol, kok kami cocok ya, ya udah deh mas, kesana-sananya ya kami jadian.

$S:$

Bagaimana kamu beradaptasi dengan keluarga di Indonesia?

E:

Keluarga saya sudah tidak mau lagi kenal dengan saya mas. Hanya satu adik saya yang masih memberikan info keluarga. Oh ya dulu dia juga gak suka saya jadi gay tapi kesininya kok dia jadi permisif kepada saya.

$S:$

Jadi kamu sudah tidak ada hubungan lagi dengan keluarga di Indonesia? Apakah kamu mau tinggal di Paris dan maaf ya kamu juga mau meninggal di Paris?

E:

Ya begitu mas. Pakde, Bude, Oom, dan Tante saya sudah gak suka kalau saya gay. Hanya adik saya yang permisif. Jadi saya yah saya putuskan untuk hidup dan meninggal di Paris. Saya sudah bilang ke suami saya di Paris kalau saya akan ikut dia ke manapun dia pergi. Kalau harus pindah lagi ke Belgia ya kami pindah. Saya sangat bersyukur memiliki dia mas. Sangat bersyukur sekali.

$\begin{array}{rlll}{ }^{9} \text { Berperilaku } & \text { sangat } & \text { kasar pada } & \text { saat } \\ \text { berhubungan seksual. } & & & \end{array}$




\section{Kesimpulan}

Daya tahan hidup seseorang tidak bekerja secara pasif dalam menghadapi kondisi lingkungannya, melainkan secara aktif memodifikasi perilaku mereka dalam rangka memelihara kondisi tertentu atau dengan kata lain mengimprovisasi kondisi yang ada. Sehingga adaptasi dapat kita sebut sebagai sebuah strategi aktif manusia dalam menghadapi lingkungannya. Adaptasi merupakan proses daya tahan.

Membaca penjelasan tentang dogma Islam dan bagaimana keluarga dimaknai oleh orang Indonesia, terutama oleh para gay muslim Indonesia, terlihat (cukup) jelas bahwa proses adaptasi merupakan proses yang sangat sulit dilalui oleh gay muslim. Adaptasi (sosial) merupakan hal yang sangat vital bagi gay muslim. Bagaimana cara mereka masuk ke dalam agama Islam dan keluarga adalah suatu proses yang penuh dengan kebohongan. Para gay muslim merekayasa hidup mereka sehingga mereka dapat masuk ke dalam lingkungan keagamaan dan keluarga. Mereka tidak ingin dimaknai sebagai "orang sakit" oleh masyarakat kebanyakan sehingga interaksi yang mereka bangun juga sangat penuh dengan ketidaksesuaian. Padahal menjadi gay bukanlah sesuatu yang salah. Agama Islam yang sangat dogmatis juga merupakan satu masalah tersendiri bagi gay yang muslim. Larangan-larangan yang selalu diberikan oleh kelompok gay memberikan suatu proses adaptasi tersendiri bagi mereka untuk bertahan hidup. Begitu pula dengan keluarga. Keluarga di Indonesia masih sangat melihat seorang anak sebagai sebuah emas. Sampai anak tersebut meninggal dunia maka anak tersebut masih menjadi tanggungan orang tuanya. Hal ini sangat berbeda dengan konsep menjadi seorang anak seperti di Eropa. Seorang anak sudah dapat keluar dari rumah mereka sejak usia belasan tahun dengan maksud mencari informasiinformasi yang mereka tidak dapatkan di dalam rumah.

\section{Daftar Pustaka}

Ahmadi, Shafiqa (2012). Islam and Homosexuality: Religious Dogma, Coloniale Rule, and the Quest for Belonging, dalam Journal of Civil Rights \& Economic Development, 26(3).

Anderson Benedict (1990). Language and Power: Exploring Political Cultures in
Indonesia, Ithaca: Cornell University Press.

Anggrahita, Hayuning (2012). L'utilisation de l'eau domestique: perception et attitudes à Jakarta (Indonésie), dalam EchoGéo, (22).

Aoki, B., C.P. Ngin, B. Mo \& D.Y. Ja. (1989). AIDS prevention models in AsianAmerican communities, dalam V. M. Mays, G.W. Albee\&S. F. Schneider (Ed.), Primary prevention of AIDS: Psychological approaches, Newbury Park, CA: Sage.

Arivia, G dan Gina B. (2016). When the State is Absent: A Study of LGBT Community in Jakarta in Indonesian Feminist Journal, (4)1, March.

Badinter, Elizabeth (1992). XY de l'identité masculine, Paris: Odile Jacob.

Barrientos, J., J. Silva, S. Catalan, F. Gomez \& J. Longuera (2010). Discrimination and victimization: Parade for lesbian, gay, bisexual, and transgender (LGBT) pride in Chile, in Journal of Homosexuality, 57(6).

Biçmen, Z \& Z. Bekiroğullari. (2014). Social problems of LGBT people in Turkey, in Procedia Social and Behavioral Sciences, 113(7/2).

Deloison, Yves (2014). L'Homme, Le Nouveau Sexe Faible. Manifeste pour un Nouveau Mâle, Paris: First Edition.

Duran, Khalid (1993). Homosexuality in Islam, dalam Homosexuality and World Religion, 181.

Elliot, Susan dan Alison Gray (2000). Family Structures, dalam Report for the New Zealand Immigration Service, New Zealand: Departement of Labour.

Forshee, Jill (2006). Culture and Customs of Indonesia, Westport, Connecticut, London: Greenwood Press.

Foucault, Michel. (1980). Herculine Barbine, New York: Random House.

Gerungan, W.A. (1991). Psikologi Sosial, Bandung: PT. Eresco.

Gruenewald, J. (2012). Are anti-LGBT Homicides in the United States unique?, in Journal of Interpersonal Violence, 27(18). 
Hareven, Tamara K. (1988). Historical Analysis of the Family, dalam Marvin B. Sussman\&Suzanne K. Steinmetz (Ed.), Handbook of Marriage and the Family, New York\&London: Plenum Press.

Ibrahim, K dan P. Songwathana (2008). Cultural Care for People Living with HIV/AIDS, in Muslim Communities in Asia: A Literature Review, dalam Thai Journal Nursing Res, 13 (2).

Johnson, Toni dan Vriens, Lauren (2011). No, Muslims are not Talking over the World, dalamThe Guardian, February 11.

Khan, Badruddin (2010). Longing, Not Belonging, and Living, dalam Fear, in Samar Habib, in Islam and Homosexuality, Volume I. California: ABC Clio.

Koentjaraningrat, R.M. (1985). Javanese culture, New York: Oxford University Press.

Mahmud, Amir (2016). Adaptasi Sebagai Strategi Bertahan Hidup Manusia, dalam $A r-$ Risalah, Vol. XVII, 1 April.

MUI. (2014). Fatwa Nomor 57 Tahun 2014 tentang Lesbian, Gay, Sodomi, dan Pencabulan. Diambil dari http://mui. or.id/wp-content/uploads/2017/02/ Lesbian-Gay-Sodomi-dan-Pencabulan. pdf.

Rassool, GH. (2000). The crescent and Islam: Healing, nursing and the spiritual dimensions. Some considerations towards an understanding of the Islamic perspectives on Caring dalam Journal Adv Nurs., 32.
Savin-Williams, Ritch C. (1990). Gay and lesbian youth: Expressions of identity, New York: Hemisphere.

Segalen, Martine (2006). Sociologie de la famille, Paris: Armand Colin.

Siker, Jeffrey S. (ed). (2007). Homosexuality and Religion. An Encylopedia, Connecticut \& London: Greenwood Press.

Usman, Munadi (2018). Lesbian Gay Bisexual and Transexual (LGBT) Polemic in Indonesia: A Study of the Opinion of the Indonesian Ulama Council and the Liberal Islam Network (JIL), dalam Islāmiyyāt, 40(2), 123-129.

Whitaker, Brian (2011). Unspeakable Love. Gay and Lesbian Life in the Middle East. London: SAQI.

Williams, Water (1991). Javanese Lives, New Brunswick, NJ: Rutgers UP.

Wirakartakusumah, D. (1997). Household Structure and the Elderly in Indonesia, dalam Laporan tidak terpublikasi Lembaga Demografi, Fakultas Ekononi dan Bisnis, Universitas Indonesia.

Yu-Rong, C.\&W. Ping (2010). Obstacles to LGBT human rights development in Taiwan, in Positions, 18(2). 